\title{
Ethics of climate change essay contest
}

\author{
Idea and coordination: Howard I. Browman, Brian M. Marcotte, Penny S. Kuhn \\ Introduction
}

\author{
Penny S. Kuhn* \\ International Ecology Institute, Nordbünte $23(+3,5,28,30), 21385$ Oldendorf/Luhe, Germany
}

According to the 'Physical sciences basis' report by the Intergovernmental Panel on Climate Change (IPCC 2007a), major consequences of climate change are now predictable to a reasonable degree of scientific certainty. The report states that by 2100 the global temperature will increase between 1.1 and $6.4^{\circ} \mathrm{C}$, with the most likely range being 1.8 to $4.0^{\circ} \mathrm{C}$. The most recent findings by Canadell et al. (2007) suggest that these predictions are in fact 'too optimistic', and that $\mathrm{CO}_{2}$ emissions are accelerating due to recent growth in the world economy and a decline in the efficiency of terrestrial and oceanic $\mathrm{CO}_{2}$ sinks. These changes - including more energetic weather, increased desertification, distribution changes of disease vectors, human suffering, habitat loss and species extinction - will continue to impact the globe geographically, socially, politically and economically (IPCC 2007b,c, Gardner 2006).

A 1 to $2^{\circ} \mathrm{C}$ increase in global mean temperature above 1990 levels is now anticipated to threaten unique environments, including many biodiversity hotspots (IPCC 2007c). Citizens in poor countries, who often use practices that are more environmentally sound than their counterparts in rich countries, are expected to be the hardest hit by climate change (IPCC $2007 \mathrm{~b}, \mathrm{c})$. These 2 points highlight the moral and ethical issues surrounding climate change. In 2001, the IPCC acknowledged that ethical considerations were needed, stating that climate change related decisions are, '...value judgments determined through sociopolitical processes, taking into account considerations such as development, equity, and sustainability, as well as uncertainty and risk' (IPCC 2001, p. 2). Upon recognition that our actions and our inaction have a direct impact on nature, our kin, distant people and future generations, those actions/inactions become open to ethical assessment (Gardner 2006). Leaders of institutions concerned with politics, law, business, medicine, science, sociology and religion will face the brunt of these changes. In the face of these challenges, their actions must be honorable, moral and ethical.

To stimulate discussion of these issues, Inter-Research Science Center sponsored several essay contests on the ethics of climate change. Subject areas which received winning entries were Economics/Business, Environmental sciences and Philosophy/Religious studies. Essays within these broad subject areas were to focus on climate change, with particular emphasis on ethical issues.

Contest judges generously volunteered their time and expertise. In the Economics/Business category they were as follows: Brendan Moyle, a bio-economist with the Department of Commerce at Massey University in Auckland, New Zealand; Hens Runhaar with the Department of Innovation and Environmental Studies at Utrecht University, The Netherlands; and Joel Smith, Vice President of Stratus Consulting, Boulder, Colorado, USA. In the Environmental sciences category the judges were as follows: Virginia Burkett, Global Change Science Coordinator with the US Geological Survey in Louisiana, USA, and an ESEP Editor; Daniel Sandweiss, the Dean and Associate Provost for Graduate Studies and Professor of Anthropology and Quaternary and Climate Studies at the University of Maine, Orono, USA; and Hans-Otto Poertner from the Alfred Wegener Institute, Biosciences division, in Bremerhaven, Germany. In the Philosophy/Religious studies category the judges were as follows: Nancy Tuana, Professor of Philosophy at Penn State University and Director of the Rock Ethics Institute in Pennsylvania, USA; Dale Jamison, Director of Environmental Studies, Professor of Environmental Studies and Philosophy, and affiliated Professor of Law at New York University, USA; and Laura Westra, Professor emeritus (Philosophy) at the University of Windsor and adjunct Professor of Social Science with York University in Toronto, Canada. 
The contest was open to graduate students (post Bachelors) at any certified university or college. The authors of the winning essays received \$1000 USD and their articles are published in the following pages. The winners for the Economics/Business, Environmental sciences, and Philosophy/Religious studies categories are, respectively, Seth Baum from Penn State University, USA, Sarah Jordaan from the University of Calgary, Canada, and Paula Posas from the University of Liverpool, UK. Congratulations to all the winners and those who participated.

\section{LITERATURE CITED}

Canadell JG, Le Quere C, Raupach MR, Field CB, and others (2007) Contributions to accelerating atmospheric $\mathrm{CO}_{2}$ growth from economic activity, carbon intensity, and efficiency of natural sinks. Proc Natl Acad Sci. doi:10.1073/pnas.0702737104

Gardiner SM (2006) A perfect moral storm: climate change, intergenerational ethics and the problem of moral corruption. Environ Values 15:397-413
IPCC (Intergovernmental Panel on Climate Change) (2001) Watson RT and the Core Writing Team (eds) Climate change 2001: synthesis report. Contributions of Working Groups I, II and III to the Third Assessment Report of the Intergovernmental Panel on Climate Change. Cambridge University Press, Cambridge. Also available online at: www.grida.no/climate/ipcc_tar/vol4/index.htm

IPCC (Intergovernmental Panel on Climate Change) (2007a) Solomon S, Qin D, Manning M, Chen Z and others (eds) The physical science basis. Contributions of Working Group I to the Fourth Assessment Report of the Intergovernmental Panel on Climate Change. Cambridge University Press, Cambridge. Also available online at: www.ipcc.ch/

IPCC (Intergovernmental Panel on Climate Change) (2007b) Parry ML, Canziani OF, Palutikof JP, van der Linden PJ, Hanson CF (eds) Impacts, adaptation and vulnerability. Contributions of Working Group II to the Fourth Assessment Report of the Intergovernmental Panel on Climate Change. Cambridge University Press, Cambridge. Also available online at: www.ipcc.ch/

IPCC (Intergovernmental Panel on Climate Change) (2007c) Summary for Policymakers of the Synthesis Report of the IPCC Fourth Assessment Report Draft copy 16 November 2007 (subject to final copy edit). Available online at: www. ipcc.ch/pdf/assessment-report/ar4/syr/ar4_syr_spm.pdf 